\title{
Monitoring Studies of Urban Air Quality in Central-Southern Spain Using Different Techniques
}

\author{
Florentina Villanueva, José Albaladejo, Beatriz Cabañas, \\ Pilar Martín and Alberto Notario \\ Castilla La Mancha University \\ Spain
}

\section{Introduction}

In urban areas, emissions of air pollutants by anthropogenic processes such as traffic, industry, power plants and domestic heating systems are the main sources of pollution (Fenger, 1999). The massive growth in road traffic and in the use of fossil fuels during the last decades has changed the composition of urban air, increasing the frequency of pollution episodes and the number of cities experiencing them. The main pollutants monitored in the atmosphere in these areas are ozone $\left(\mathrm{O}_{3}\right)$, nitrogen oxides $\left(\mathrm{NO}_{\mathrm{x}}\right)$, sulphur dioxide $\left(\mathrm{SO}_{2}\right)$, carbon monoxide (CO), aromatic compounds and particulate matter. While $\mathrm{CO}, \mathrm{NO}$ and aromatic compounds are mainly emitted by traffic, $\mathrm{O}_{3}$ and $\mathrm{NO}_{2}$ are originated by photochemical reactions.

The high levels of solar irradiation observed in the Mediterranean countries favour, in general, the enhanced photochemical production of secondary oxidising pollutants, including $\mathrm{O}_{3}$, nitrogen dioxide $\left(\mathrm{NO}_{2}\right)$, and peroxyacetylnitrate (PAN). Amongst these, the $\mathrm{O}_{3}$ and the nitrogen dioxide $\left(\mathrm{NO}_{2}\right)$ are capable of causing adverse impacts on human health and the environment (Lee et al., 1996; WHO, 2000a; Mazzeo and Venegas, 2002, 2004).

Nitrogen dioxide is considered to be an important atmospheric trace gas pollutant not only because of its effects on health but also because (a) it absorbs visible solar radiation and contributes to impaired atmospheric visibility, (b) as an absorber of visible radiation, it could play a potentially direct role in the change in the global climate if its concentrations were to become high enough (WHO, 2000a), (c) it is one of the major sources of acid rain (Tang and Lau, 1999), (d) it is, along with nitric oxide (NO), a chief regulator of the oxidising capacity of the free troposphere by controlling the build-up and fate of radical species, including hydroxyl radicals, and (e) it plays a critical role in determining concentrations of $\mathrm{O}_{3}$, nitric acid $\left(\mathrm{HNO}_{3}\right)$, nitrous acid $\left(\mathrm{HNO}_{2}\right)$, organic nitrates such as $\mathrm{PAN}\left(\mathrm{CH}_{3} \mathrm{C}(\mathrm{O}) \mathrm{O}_{2} \mathrm{NO}_{2}\right)$, nitrate aerosols and other species in the troposphere. In fact, the photolysis of nitrogen dioxide in the presence of volatile organic compounds is the only key initiator of the photochemical formation of ozone and photochemical smog, whether in polluted or unpolluted atmospheres (WHO, 2000a; Varshney and Singh, 2003). Therefore, ozone mainly 
generated in the photochemical reaction mentioned above, is a secondary pollutant. Ozone is also produced by natural sources (trees and thunderstorms for example).

It has been found out that the photochemical ozone production in urban areas rises with the NOx emissions and is less sensitive to the VOC emissions (Sillman and Samson, 1995). In areas moderately contaminated, ozone sensitivity to emission of nitrogen oxides depends on the season and on the emission rates (Kleinman, 1991).

Hence, monitoring of air pollution is necessary, not only to comply with the environmental directives, but also to provide public information and to measure the effectiveness of emission control polices. It is also important to have a number of measurements from different cities to help understand the role of the different physicochemical processes in the troposphere. In addition to meteorological and irradiance conditions, traffic patterns, volatile organic compounds (VOC)/NOx emissions and industrial activities vary significantly between different locations.

Monitoring of urban air pollutants has been the subject of study in the city of Ciudad Real (in central-southern Spain) using passive and continuous techniques in order to identify, measure and study the daily, weekly and seasonal variation of the concentrations of important tropospheric constituents (Saiz-Lopez et al., 2006, Martín et al., 2010 and Villanueva et al., 2010). Therefore, a review of these studies has been presented in this chapter, where the evolution of air quality during three different periods (July 2000-March 2001; January-December 2007; March-December 2008) is shown and data of $\mathrm{O}_{3}, \mathrm{NO}_{2}$ and $\mathrm{SO}_{2}$ are compared.

\section{Material and methods: Experimental section}

\subsection{Area of study}

The study was carried out in the urban area of Ciudad Real (Spain). The city has around 65,000 inhabitants and is located in the heart of La Mancha region in central-southern Spain $(38.59 \mathrm{~N}, 3.55 \mathrm{~W}$, at approximately $628 \mathrm{~m}$ above sea level) in a fairly flat area, $200 \mathrm{~km}$ south of Madrid. With a low presence of industry, traffic is likely to be the most important source of air pollution in this city. Meteorologically, the zone is characterised by very hot and dry summer period with high insulation, variable direction winds and dry and cold winters, conditions that could play an important role in the evolution of the polluting agents.

A DOAS system, passive samplers and a mobile air pollution control station were used to sample, measure and identify the different pollutants. A map of the city is shown in Figure 1 , where the situation of the all measurement points can be seen. The passive samplers were placed in town centre (total sampling area of $7.5 \mathrm{~km}^{2}$ approximately) with the exception of points 6, 7 and 10 that correspond to rural zones, but in the case of point 10 in the influence zone of a small airport under construction. Industry next to the city is especially scarce, and the zone is mainly surrounded by rural areas. There is a petrochemical complex located in Puertollano at $30 \mathrm{~km}$ from southwest of Ciudad Real. This complex would affect to increase the $\mathrm{NO}_{2}$ and $\mathrm{O}_{3}$ concentrations in the Ciudad Real atmosphere by transporting processes.

The DOAS instrument was placed at a fixed location inside the campus of the University of Castilla-La Mancha, situated in the Eastern part of the city and downwind of the main traffic 
of the city (also point 1 ). The mobile station (point MS) was also placed, at a fixed location located between the town centre and the ring road. This site represents well-mixed urban air conditions near major anthropogenic sources of primary pollutants such as traffic.

The measurements were carried out in different periods of time, the pollutants were monitored by means of DOAS from 21st July 2000 to $23^{\text {rd }}$ March 2001, the passive sampling were carried out from January to December 2007 and the mobile station monitored the pollutants from March to December 2008.

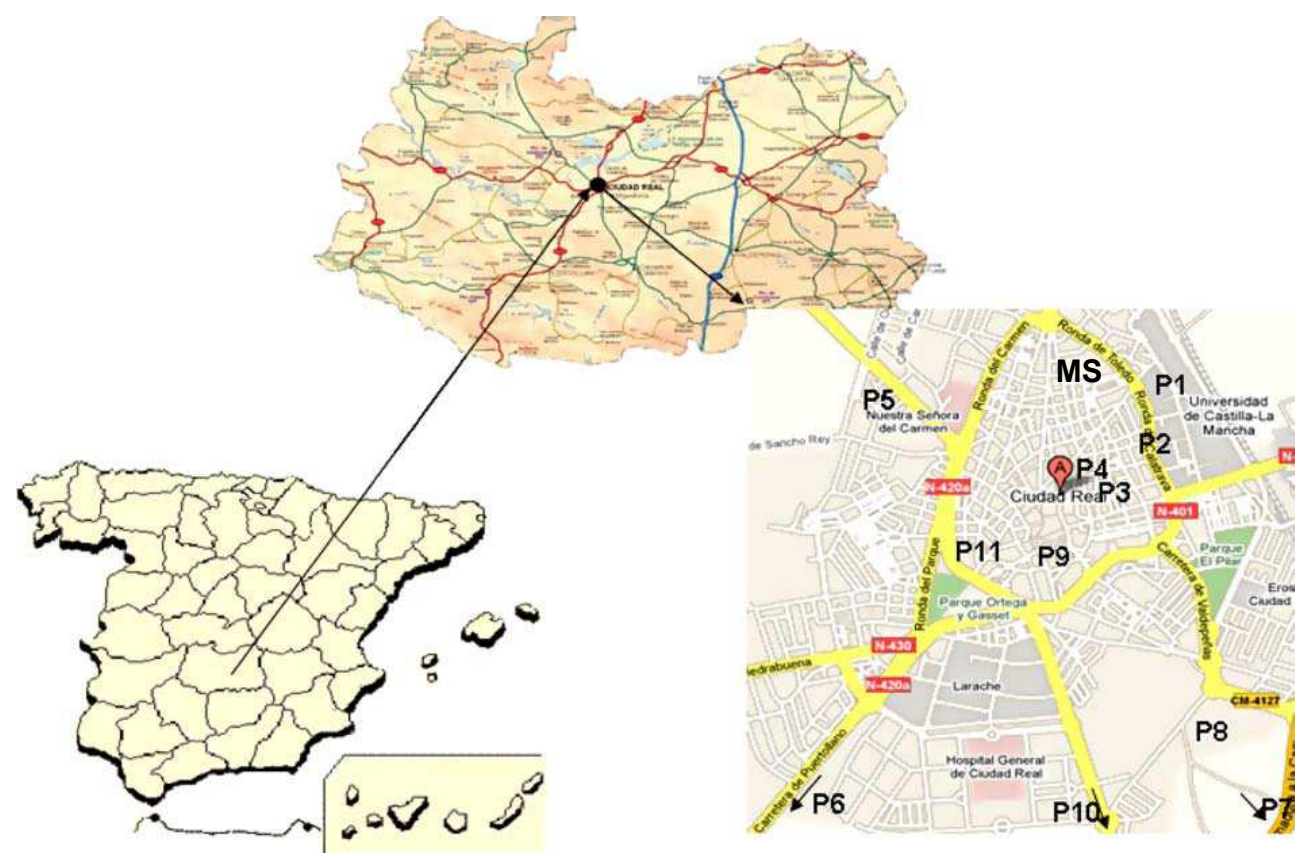

Fig. 1. Situation map of Ciudad Real (Spain) and the sampling points of passive samplers. P1 (DOAS and one passive sampler), MS (Mobile station).

\subsection{Description of experimental techniques}

\subsubsection{DOAS technique}

The DOAS principle and instrumentation have proven to be a powerful tool for simultaneously monitoring relevant atmospheric trace gases (Platt, 1994; Plane and SaizLopez, 2005). The use of light paths which range from hundred of meters to several kilometres can avoid the problems of local influences and surface effects, as the measured concentrations are averaged over the light path and are barely influenced by small-scale perturbations. The technique is based on the fact that all trace gases absorb electromagnetic radiation in some part of the spectrum. If the radiation of the appropriate frequency is transmitted through the atmosphere, the absorption features of each molecule in that spectral region allow the identification and quantification of the gas concentration. A commercial DOAS system (OPSIS, model AR 500) was employed to simultaneously monitor 
the gas concentration of $\mathrm{O}_{3}, \mathrm{NO}_{2}, \mathrm{NO}$, and $\mathrm{SO}_{2}$ integrated along a light path of $391 \mathrm{~m}$. More experimental details are described in Saiz-Lopez et al., 2006 and only a brief description is made. The system used in this study consists of an emitter (EM 150) and receiver (RE 150) in combination with the AR 500 analyzer. The emitter was located on the roof of the School of Agricultural Studies about $16 \mathrm{~m}$ above the ground, and the receiver system was installed $12 \mathrm{~m}$ above street level, on a terrace on the School of Computing Science.

The average altitude of the optical path was $14 \mathrm{~m}$ above ground level. The $391 \mathrm{~m}$ light beam crosses over a small parking area and is nearby two interior city roads containing the heaviest traffic in the city. Also, a monitoring station of the National Meteorological Institute was located in the middle of the light path and provided surface meteorological data for the interpretation of the measurements in this study. In the evaluation procedure (Platt, 1994; Plane and Saiz-Lopez, 2005), the wavelength region of the strongest absorption was used for each gas: $200-250 \mathrm{~nm}(\mathrm{NO}), 250-300 \mathrm{~nm}\left(\mathrm{O}_{3}\right), 360-440 \mathrm{~nm}\left(\mathrm{NO}_{2}\right)$ and $260-340 \mathrm{~nm}\left(\mathrm{SO}_{2}\right)$. The calibration of the DOAS system was made using the cell reference system provided by the manufacturer (an OPSISCB100 calibration bench with cells of various lengths, a calibration lamp CA 150 and an OPSIS OC 500 ozone calibrator unit). For the pollutants monitored, the manufacturer specifies a detection limit of the order of $1 \mu \mathrm{g} \mathrm{m}^{-3}$ and an accuracy of $2 \%$ for $\mathrm{NO}_{2}, \mathrm{SO}_{2}$ and $\mathrm{O}_{3}$ and $3 \%-15 \%$ for $\mathrm{NO}$.

\subsubsection{Passive sampling technique}

Passive samplers are based on free flow (according to the Fick's first law of diffusion) of pollutant molecules from the sampled medium to a collecting medium. These devices can be deployed virtually anywhere, being them useful for mean concentrations determinations. Radiello ${ }^{\circledR}$ samplers (Fondazione Salvatore Maugeri, Padova, Italy) have been employed to measure ambient $\mathrm{NO}_{2}$ and ozone concentrations. Radiello passive samplers are different from the axial ones because the diffusion process is radial through a microporous cylinder in which a cartridge with adsorbent material is positioned. Consequently, there is a greater diffusion area, which facilitates the reaction between the gas and the collection cartridge (Cocheo et al., 1999), giving an uptake rate of at least two times higher.

Radiello passive samplers were used to describe the evolution of $\mathrm{NO}_{2}$ and $\mathrm{O}_{3}$ levels in the urban air of Ciudad Real throughout the four seasonal periods during 2007. The Radiello sampler for measuring nitrogen dioxide and $\mathrm{O}_{3}$ is based on the principle that $\mathrm{NO}_{2}$ and $\mathrm{O}_{3}$ diffuse across the diffusive body towards the absorbing material on the inner cartridge. $\mathrm{NO}_{2}$ and $\mathrm{O}_{3}$ in the atmosphere are captured in the sampler as nitrite $\left(\mathrm{NO}_{2}{ }^{-}\right)$and 4pyridylaldehyde, respectively. According to the Fick's first law, the quantity of $\mathrm{NO}_{2}{ }^{-}$and 4pyridylaldehyde in the sampler is proportional to the concentration outside the sampler, the diffusion coefficient, the dimensions of the sampler and the sampling time. Concentrations are calculated from the quantity of nitrite or 4-pyridylaldehyde captured in the sampler by means of Eq. 1:

$$
C\left(\mu g m^{-3}\right)=\frac{m \times z}{A \times t \times D} 10^{6}=\frac{m}{Q_{k} t} 10^{6}
$$

Where the sampling rate $Q_{k}$ is constant: 


$$
Q_{k}\left(m L \min ^{-1}\right)=60 x D x \frac{A}{z}
$$

$\mathrm{C}$ represents the ambient air $\mathrm{NO}_{2}$ or $\mathrm{O}_{3}$ concentration measured by the passive sampler (micrograms per cubic metre), $\mathrm{m}$ is the quantity of $\mathrm{NO}_{2}$ or $\mathrm{O}_{3}$ captured in the sampler (micrograms) and $\mathrm{z}, \mathrm{A}, \mathrm{t}$ and $\mathrm{D}$ denote the diffusion length (centimetres), cross-sectional area (square centimetres), sampling time (minutes) and diffusion coefficient (square centimetres per second), respectively. Exposure time to sample $\mathrm{NO}_{2}$ and $\mathrm{O}_{3}$ was in all points 7 days. Details of the extraction and analysis procedure of the samples are given in Martín et al., 2010 according with R\&P-Co 2001. In all cases, three unused cartridges belonging to the same lot were treated in the same manner as the samples. Then, it was subtracted by the average blank value from the absorbance values of the samples.

\subsubsection{Mobile air pollution control station}

A Mercedes Sprinter van was selected as rolling platform for the measuring equipment. The mobile air pollution control station is equipped with a vertical manifold that distributes the sample to all the analyzers, a multipoint calibrator (API, model 700) with an internal ozone calibrator and photometer, a zero air generator (API, model 701) and a meteorological station. Table 1 presents a list of the characteristics of the instruments and measured parameters including meteorological parameters. The methods used to analyze the different air pollutants are those used by the Air-Quality Networks and therefore, defined by the European Directive (2008/50/CE), as reference methods.

The particulate matter analyzer is based on beta radiation absorption technique and has been designated by the American Environmental Protection Agency (EPA) as equivalent method for measuring the $\mathrm{PM}_{10}$ fraction of suspended matter (EQPM-0798-122). The calibration of the photometer and flows of the calibrator and analyzers was made at the beginning of the measurement period by the accredited calibration laboratory of the manufacturer. More experimental details are described in Villanueva et al., 2010.

\begin{tabular}{|l|l|l|l|}
\hline Parameter & Instrument & $\begin{array}{l}\text { Time } \\
\text { resolution }\end{array}$ & Detection limit \\
\hline $\mathrm{O}_{3}$ & API 400A & $20 \mathrm{~s}$ & $0.6 \mathrm{ppb}$ \\
\hline $\mathrm{NOx}$ & API 200A & $20 \mathrm{~s}$ & $0.4 \mathrm{ppb}$ \\
\hline $\mathrm{SO}_{2}, \mathrm{H}_{2} \mathrm{~S}$ & API 100A & $20 \mathrm{~s}$ & $0.4 \mathrm{ppb}$ \\
\hline $\mathrm{CO}$ & API 300A & $20 \mathrm{~s}$ & $0.04 \mathrm{ppm}$ \\
\hline $\mathrm{BTX}$ & Syntech spectras GC 955 & $15 \mathrm{~min}$ & $0.05 \mathrm{ppb}$ for benzene \\
\hline $\mathrm{PM}_{10}$ & Met One BAM 1020 & $1 \mathrm{~h}$ & $1 \mu \mathrm{g} / \mathrm{m}^{3}$ \\
Temperature and humidity & Met One HP043 & $10 \mathrm{~s}$ & $-40^{\circ} \mathrm{C} / 0 \%$ \\
Pressure & Met One 091 & $10 \mathrm{~s}$ & $0 \mathrm{mbar}$ \\
Wind direction and speed & Met One 50.5 & $10 \mathrm{~s}$ & $0.5 \mathrm{~m} / \mathrm{s}$ \\
Solar radiation & Met One 595 & $10 \mu \mathrm{s}$ & $--\mathrm{m}^{2}$ \\
Rain & Met One RC15 & -- & - \\
\hline
\end{tabular}

Table 1. Monitoring instruments employed in the mobile monitoring platform. 


\section{Results and discussion}

\subsection{Measurements of $\mathrm{O}_{3}, \mathrm{NO}$ and $\mathrm{NO}_{2}$}

The evolution of $\mathrm{NO}, \mathrm{NO}_{2}$ and $\mathrm{O}_{3}$ concentration measured using the continuous techniques DOAS (Saiz-Lopez et al., 2006) and the mobile station (Villanueva et al., 2010) for a typical summer day are shown in Figure 2a and 2b, respectively.

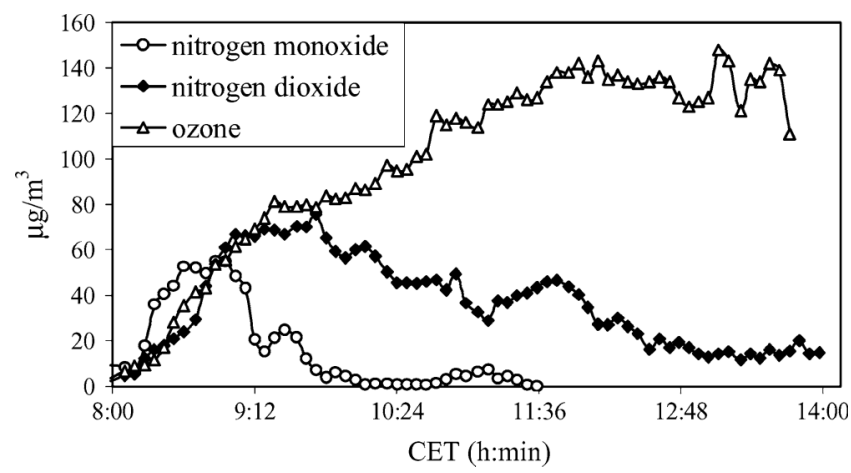

a)

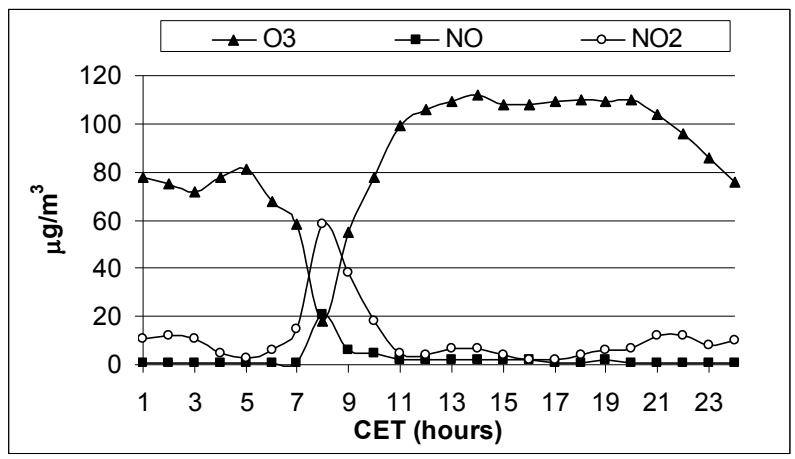

b)

Fig. 2. Evolution of $\mathrm{O}_{3}, \mathrm{NO}$ and $\mathrm{NO}_{2}$, concentrations for a typical summer day in Ciudad Real measured (a) with DOAS (12 th August 2000) and (b) with the mobile station (30th July 2008). Time scale is given in CET (Central European Time). CET=UTC+2 in summer; UTC (Universal time coordinated).

It can be seen a typical profile for the three pollutants that is similar in both cases during the time period from 10:00 to 14:00. The maximum of NO concentrations in the early morning (see figure $2 b$ ) corresponds with the minimum of $\mathrm{O}_{3}$. This morning $\mathrm{O}_{3}$ loss has been previously studied by Zhang et al., 2004. Their results suggested that $\mathrm{O}_{3}$ concentrations are depressed by the reaction of $\mathrm{NO}+\mathrm{O}_{3} \rightarrow \mathrm{NO}_{2}$. During daytime, $\mathrm{NO}_{2}$, can be quickly photodisassociated (in a few minutes) and yield $\mathrm{O}_{3}$. Therefore, as the day progresses, solar radiation levels favour the increase in the $\mathrm{O}_{3}$ concentrations, having as consequence a 
decrease in $\mathrm{NO}$ and $\mathrm{NO}_{2}$. After sunset, the cease in solar activity decreases the $\mathrm{O}_{3}$ concentrations. The diurnal cycles registered in both studies (Saiz-Lopez et al., 2006 and Villanueva et al., 2010) show that the urban atmosphere of Ciudad Real is mainly influenced by road traffic and photochemistry. This behavior was observed in other urban areas of Spain and Europe (Palacios et al., 2002 and Kourtidis et al., 2002).

Figure 3 shows the evolution of $\mathrm{NO}, \mathrm{NO}_{2}$ and $\mathrm{O}_{3}$ concentrations observed for an autumn day with the analyzers of the mobile station. It can be seen a negative correlation between $\mathrm{O}_{3}$ and $\mathrm{NO}_{2}$ as it occurred in summer-time and also an additional peak for $\mathrm{NO}_{2}$ and $\mathrm{NO}$ after sunset which is related to a second rush hour in the traffic circulation. In this case the drop in $\mathrm{O}_{3}$ concentration must be mainly due to the reaction with NO because of the absence of solar radiation. The same behavior was observed in 2001 with the DOAS system (Saiz-Lopez et al., 2006).

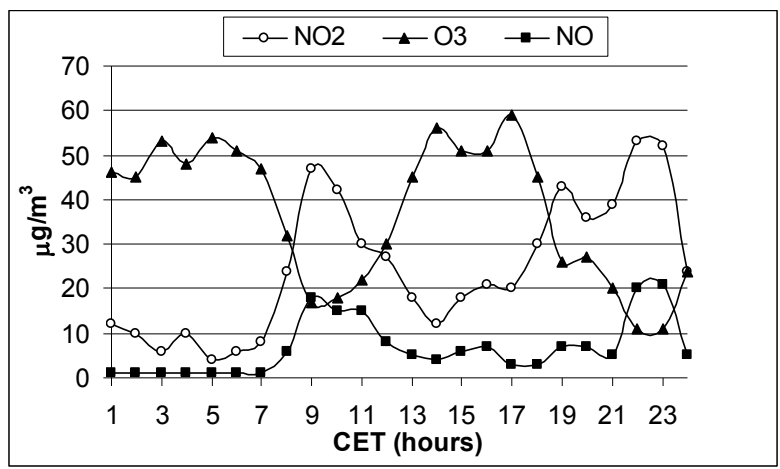

Fig. 3. Example of the evolution of $\mathrm{O}_{3}, \mathrm{NO}$ and $\mathrm{NO}_{2}$ concentrations for an autumn day (12nd December 2008) in Ciudad Real. Time scale is given in CET (Central European Time), being $\mathrm{UTC}+1$ in autumn.

Figure 4 shows the daily averaged mixing ratio of $\mathrm{NO}_{2}$ and $\mathrm{O}_{3}$ measured by the DOAS technique (Saiz-Lopez et al., 2006) and figure 5 the weekly variation of $\mathrm{O}_{3}$ and $\mathrm{NO}_{2}$ using passive sampling (Martin et al., 2010). Finally, monthly averaged concentrations for NO, $\mathrm{NO}_{2}$ and $\mathrm{O}_{3}$ obtained from mobile station (Villanueva et al., 2010) are represented in figure 6 (in all cases during the whole measurements period). As it can be seen, the annual cycle for these trace gases show the largest values of $\mathrm{O}_{3}$ during summer while $\mathrm{NO}_{2}$ exhibit maximum value in winter or autumn months. On average, the production of $\mathrm{O}_{3}$ is reduced in autumn-winter by up to $60 \%$ compared to the summer months. Maximum monthly averages of $\mathrm{O}_{3}$, (in summer) and $\mathrm{NO}_{2}$ (in autumn-winter) were: with DOAS, 65 and $35 \mu \mathrm{g} \mathrm{m}^{-3}$, with passive samplers 48 and $24 \mu \mathrm{g} \mathrm{m}^{-3}$ and 82 and 18,6 $\mu \mathrm{g} \mathrm{m}^{-3}$ with the analyzers of the mobile station.

The increase of ozone concentration in spring observed in the case of passive samplers, where several sampler points were located outside of downtown, could be due to emitted volatile organic compounds of biogenic origin (BVOCs), which reach the maximum levels in the spring period as a result of the intense activity of plant species and the photochemical associated. In the presence of nitrogen oxides (NOx) and under particular weather 
conditions (supporting photochemistry), BVOC contribute to the formation in the troposphere of secondary pollutants such as ozone (Atkinson, 2000 and Fuentes et al., 2000). Nevertheless, in rural areas with high levels of BVOCs the formation of ozone may be NOxlimited. In this sense, meteorological conditions and the dominating trajectories of air masses can constitute a source of NOx. Thus, there are several meteorological conditions that may enhance the rise on surface ozone during the spring season. In these months the heating of the ground favors the formation of higher mixing layers, mostly in continental areas such as the studied region, and therefore the photochemical activity inside them is elevated. This increase in $\mathrm{O}_{3}$ concentration in spring is also observed for the points in which DOAS and the mobile station are located in the urban area.

Regarding NOx, the highest values found in winter and autumn months must be related with the lesser solar radiation and lower temperature which reduce the photochemical activity. Therefore, the oxidation of NO from motor traffic and central heating systems will increase the concentration of $\mathrm{NO}_{2}$ and it will tend to accumulate due to the less photochemical activity in this period. Also, the reduction of the photochemical production of $\mathrm{O}_{3}$ will favour the removal of this molecule by reaction with $\mathrm{NO}$ to form $\mathrm{NO}_{2}$ and $\mathrm{O}_{2}$, which in turn will contribute of the enhancement of the $\mathrm{NO}_{2}$ values.
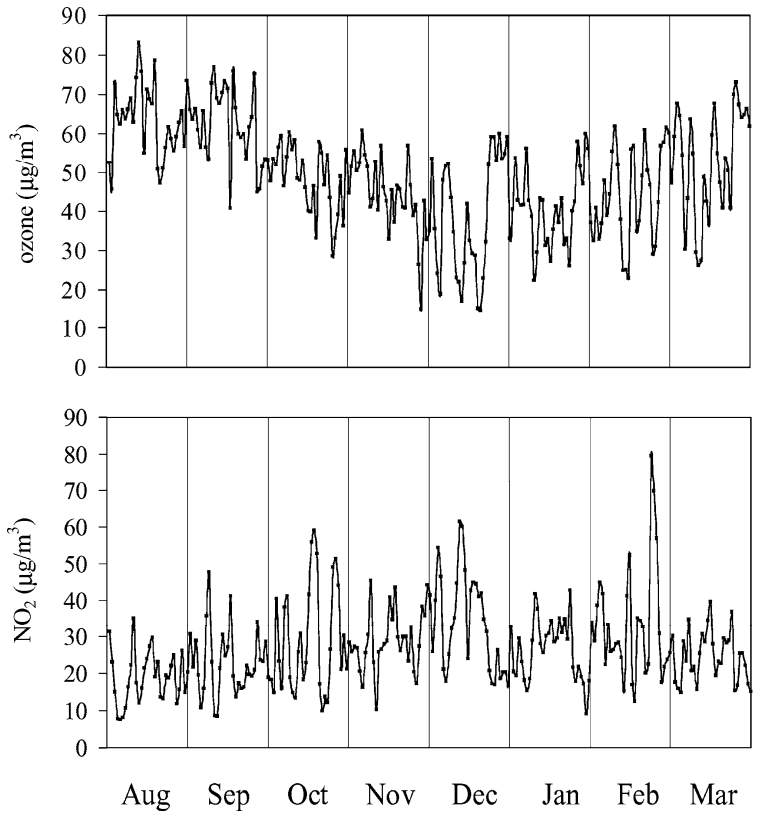

Fig. 4. Daily mean concentration data for $\mathrm{O}_{3}$ and $\mathrm{NO}_{2}$ obtained from the DOAS dataset for the whole period of measurements (August 2000-March 2001). 


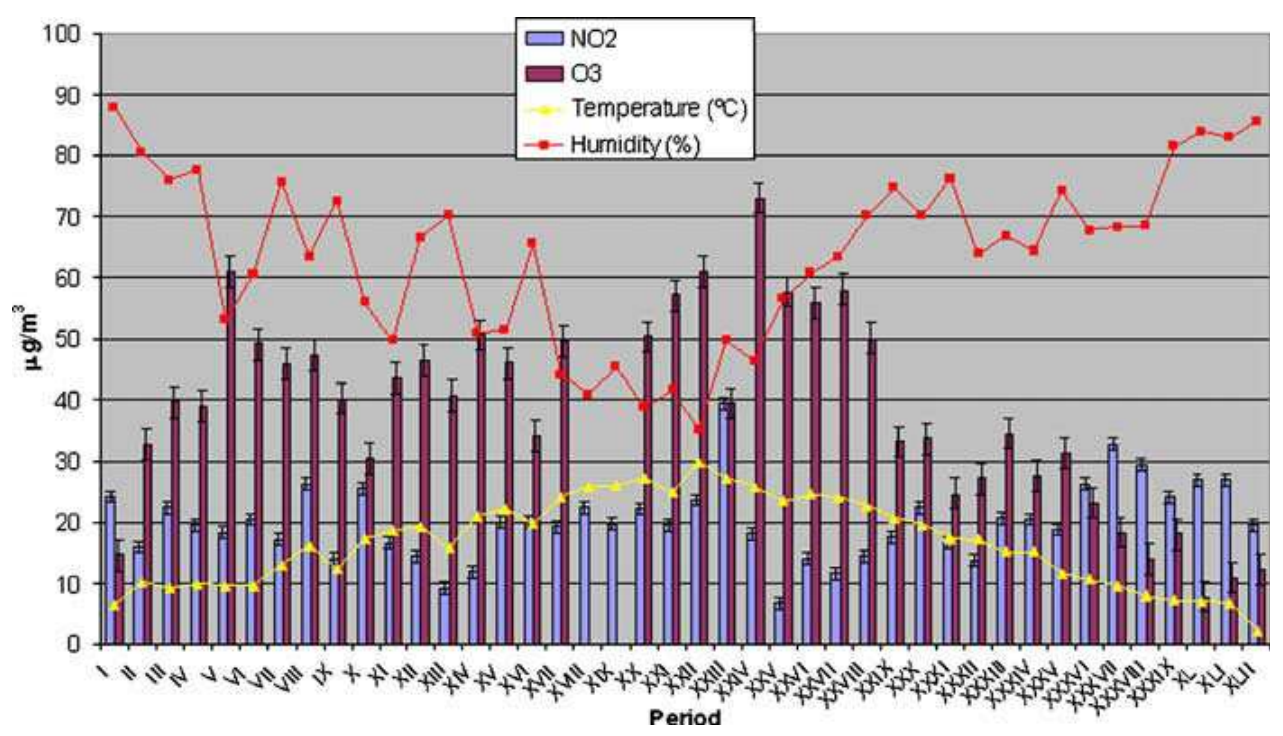

Fig. 5. Evolution of temperature, humidity, $\mathrm{NO}_{2}$ and $\mathrm{O}_{3}$ average concentrations of the 11 measured points during the full period (January-December 2007) using passive samplers. Winter (I-V), Spring (VI-XVI), Summer (XVII-XXX) and Autumn (XXXI-XLII).

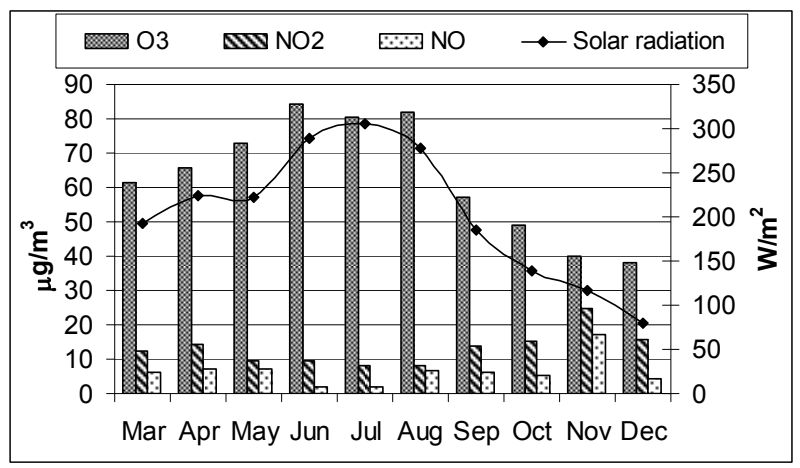

Fig. 6. Monthly means of $\mathrm{O}_{3}, \mathrm{NO}_{2}$ and $\mathrm{NO}$ pollutants measured from daily data (MarchDecember 2008) with the analyzers of the mobile station. Solar radiation has also been plotted.

Mean annual levels for $\mathrm{O}_{3}$ and $\mathrm{NO}_{2}$ were 50 and $27 \mu \mathrm{g} \mathrm{m}^{-3}$ with DOAS, 38 and $20.8 \mu \mathrm{g} \mathrm{m}^{-3}$ with passive samplers and 63 and $13 \mu \mathrm{g} \mathrm{m}^{-3}$ for the mobile station. Mean annual levels for $\mathrm{O}_{3}$ and $\mathrm{NO}_{2}$ at $\mathrm{P} 1$, the point nearest to DOAS and mobile station was 42.5 and $16 \mu \mathrm{g} \mathrm{m}^{-3}$. The values reported here are generally lower than those observed in previous studies in large urban areas in Spain, such as Madrid (Pujadas et al., 2000; Palacios et al., 2002) and Barcelona (Toll and Baldasano, 2000), where traffic emissions are considerably higher. 
One advantage of using passive samplers is the ability to develop a spatial distribution map. In this sense, the $\mathrm{O}_{3}$ and $\mathrm{NO}_{2}$ average values obtained in the points P1, P2, P3, P4, P5, P6, P8, P9 and P11 have been used to create the spatial distribution map of these pollutants (Fig. 7) using SurGe Project Manager ver 1.4. As it can be seen, higher values of $\mathrm{O}_{3}$ correspond to lower values of $\mathrm{NO}_{2}$ and vice versa. This behaviour is expected considering the interconversion of both species according to photochemical cycle of tropospheric $\mathrm{O}_{3}$ production (Finlayson-Pitts and Pitts, 2000). This same behaviour was also observed in the case of analysis by DOAS and conventional analyzers.
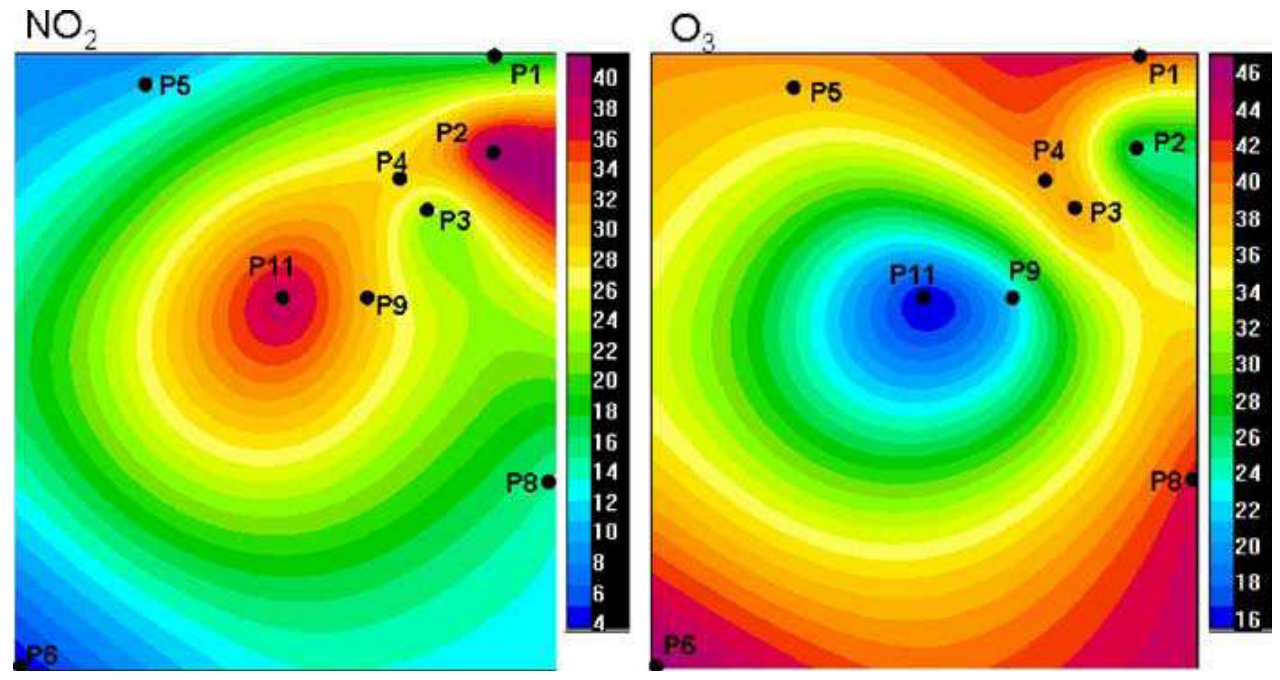

Fig. 7. Maps of $\mathrm{O}_{3}$ and $\mathrm{NO}_{2}$ spatial distribution. Units are in $\mu \mathrm{g} \mathrm{m}^{-3}$.

As commented above, meteorological conditions can affect the pollutant transport and distribution. Ozone concentration (in $\mu \mathrm{g} \mathrm{m}^{-3}$ ) from data obtained by passive samplers, showed a slight negative correlation with relative humidity $\left(\mathrm{RH}\right.$ in \%) $\left(\left[\mathrm{O}_{3}\right]=-0.62 \mathrm{RH}+\right.$ 88.66) and a positive correlation with temperature ( $\mathrm{T}$ in degree Celsius; $\left[\mathrm{O}_{3}\right]=0.37 \mathrm{~T}+2.52$ ). Periods with higher temperatures and lower humidity usually correspond to higher values of ozone (Martin et al., 2010). In the case of DOAS analysis, the wind speed does not significantly influence the $\mathrm{NO}_{2}$ observations in winter, by contrast, in summer, higher influence of the wind speed in the $\mathrm{NO}_{2}$ concentrations is observed with a decreasing trend on $\mathrm{NO}_{2}$ as the wind speed increases. The higher thermal convection (associated with larger eddy diffusion coefficients) and the faster winds in summer will contribute to a more efficient mixing leading to a higher dependence of the $\mathrm{NO}_{2}$ values with wind speed as observed by the DOAS (Saiz-Lopez et al., 2006).

Regarding limit and threshold environmental levels values, the European Directive 2008/50/EC for $\mathrm{O}_{3}$ establishes a population information threshold defined as an hourly average of $180 \mu \mathrm{g} \mathrm{m}^{-3}$. Results obtained from DOAS in summer of 2000 and from mobile station in summer of 2008, showed that this value was exceeded only one time during summer season in 2008, with a concentration of $191 \mu \mathrm{g} \mathrm{m}^{-3}$. In addition, the annual mean values of 50, 47 (point P6) and $63 \mu \mathrm{gm}-3$ measured in 2000, 2007 and 2008 exceeded the 
threshold limit value (40 $\mu \mathrm{g} \mathrm{m}^{-3}$ calendar year) which implies damage to materials. The values obtained for $\mathrm{NO}_{2}$ in points $\mathrm{P} 2$ and P11 slightly exceeded the annual limit value for the protection of vegetation $\left(30 \mu \mathrm{g} \mathrm{m}^{-3}\right)$ and human health $\left(40 \mu \mathrm{g} \mathrm{m}^{-3}\right)$.

\subsection{Measurements of $\mathrm{SO}_{2}$}

The levels of $\mathrm{SO}_{2}$ in the urban atmosphere of Ciudad Real during August 2000 to March 2001 and March to December 2008 were monitored using the continuous remote-sensing technique DOAS and the $\mathrm{SO}_{2}$ analyzer placed at mobile station. The data obtained are shown in Figure 8 (a) and 8 (b) respectively.

a)

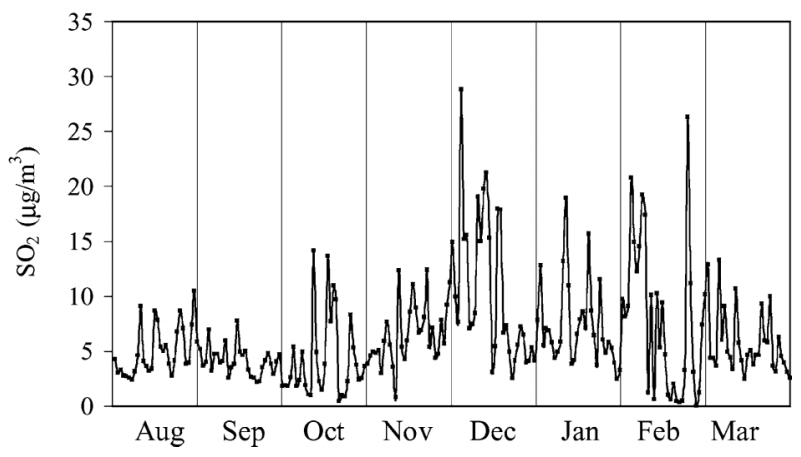

b)

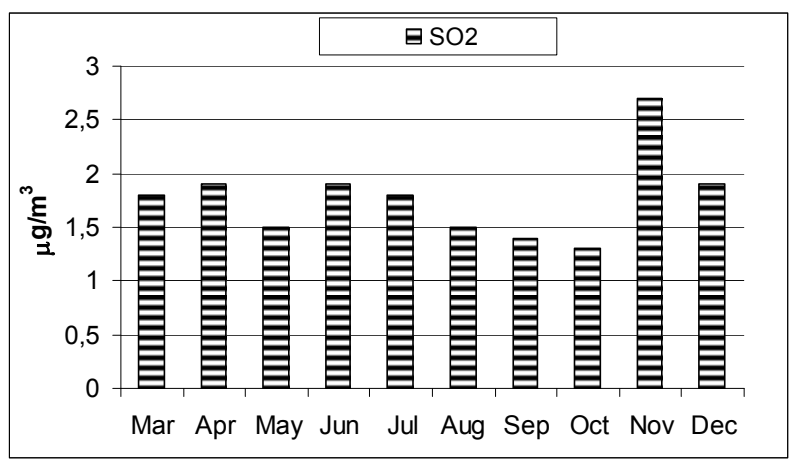

Fig. 8. (a) Daily mean concentration data for $\mathrm{SO}_{2}$ obtained from the DOAS dataset for the entire period of measurements (August 2000-March 2001) and (b) monthly mean concentration data obtained from mobile station (March -December 2008).

The daily mean concentration profile obtained with DOAS system shows clearly an increase in the concentration of $\mathrm{SO}_{2}$ during winter being the maximum monthly average of $10 \mu \mathrm{g} \mathrm{m}^{-3}$ in December 2000. $\mathrm{SO}_{2}$ mean values were two times higher in winter than in summer. In the case of mobile station there is not a clear difference throughout the months, the maximum monthly average was $2.7 \mu \mathrm{g} \mathrm{m}^{-3}$ in November 2008 what means a $73 \%$ less than the maximum value found in 2000. Mean annual levels were $7 \mu \mathrm{g} \mathrm{m}^{-3}$ measured with DOAS system and $1.8 \mu \mathrm{g} \mathrm{m}^{-3}$ measured with the mobile station. 
A diurnal profile of $\mathrm{SO}_{2}$ for summer and winter time, hourly averaged, is illustrated in Figure 9. The higher $\mathrm{SO}_{2}$ concentrations in winter were mainly related to house heating and only at a small extent with road traffic. The main difference between them arises in the later part of the day (i.e. $16 \mathrm{~h}$ to $22 \mathrm{~h}$ ). In the case of the January data, the concentration of $\mathrm{SO}_{2}$ increases up to three times in the early evening hours, when central heating systems (widely employed in this city during the cold winter months) are in greater use. The diurnal variation of $\mathrm{SO}_{2}$ is also characterised by a secondary small peak observed in the morning, at the rush hour of traffic. In the warm season, only this small peak at the rush hour is observed. This small peak is broader in August indicating a change in the traffic pattern in this vacational month and/ or another source of $\mathrm{SO}_{2}$.

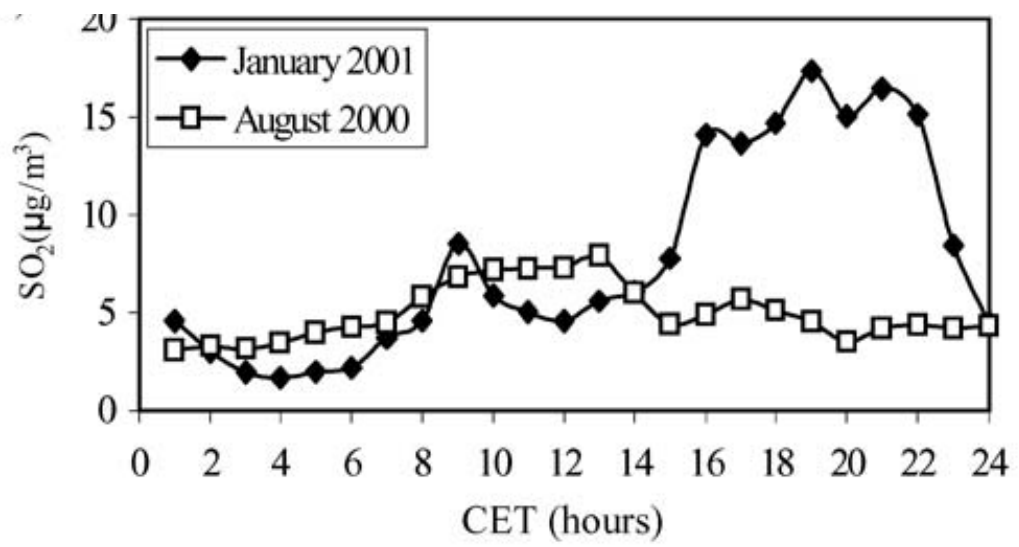

Fig. 9. Mean diurnal variation of the hourly averaged concentration during August 2000 and January 2001. Time scale is given in CET (Central European Time), being UTC+1 in winter and UTC +2 in summer.

Generally, the levels of $\mathrm{SO}_{2}$ registered in Ciudad Real during 2000/2001 and 2008 were found to be lower than those encountered in similar studies on other European cities (Gobiet et al., 2000; Vandaele et al., 2002; Kourtidis et al., 2002).

\subsection{Measurements of CO, BTX and $\mathrm{PM}_{10}$}

The concentrations of $\mathrm{CO}, \mathrm{PM}_{10}$ and benzene, toluene and $\mathrm{m}, \mathrm{p}$-xylene (BTX) were reported for the first time in Ciudad Real (Villanueva et al., 2010) using the mobile station.

Figure 10 shows the evolution of BTX, $\mathrm{CO}$ and $\mathrm{PM}_{10}$ concentrations observed for an autumn day. As above mentioned, the daily evolution of air pollutants reveals a marked daily cycle as in the cases of $\mathrm{O}_{3}$ and $\mathrm{NO}_{2}$. The daily evolution of $\mathrm{O}_{3}$, and $\mathrm{NO}$ and their relation with $\mathrm{BTX}$ is due to common NO and BTX sources and the photochemical mechanism involving these species (NO, $\mathrm{NO}_{2}, \mathrm{BTX}$, among others) that leads to $\mathrm{O}_{3}$ formation (Finalyson-Pitts and Pitts, 2000). Two peaks are observed during the day, one in the early morning hours when the emissions from road traffic increase and other after sunset which is related to a second rush hour in the traffic circulation. During summer, only the first peak corresponding to the early morning hours appears as in the cases of $\mathrm{NO}$ and $\mathrm{NO}_{2}$. 

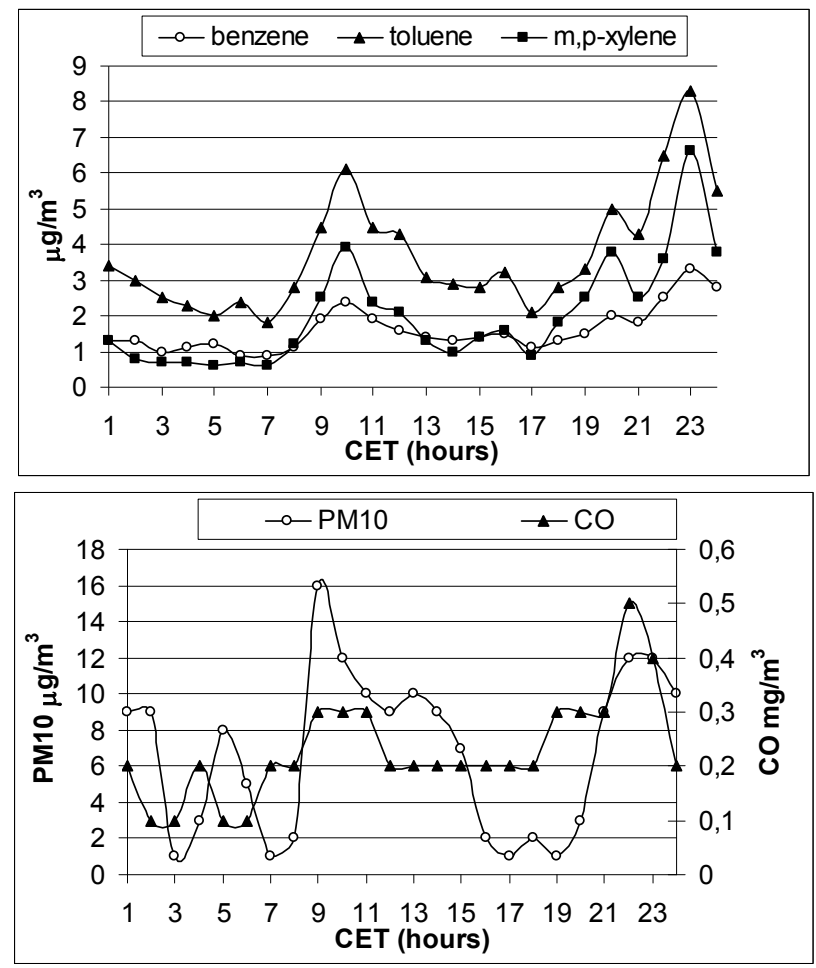

Fig. 10. Example of the evolution of BTX, $\mathrm{CO}$ and $\mathrm{PM}_{10}$ concentrations for an autumn day (12 ${ }^{\text {nd }}$ December 2008) in Ciudad Real. Time scale is given in CET (Central European Time), being UTC+1 in autumn.

Figure 11 shows the monthly averaged concentrations for CO, PM10 and BTX during the whole period of measurement. For PM10, there is not a clear trend throughout the months, while for $\mathrm{CO}$ the highest values are registered in spring, $0.19 \mathrm{mg} \mathrm{m}^{-3}$ and autumn, $0.21 \mathrm{mg}$ $\mathrm{m}^{-3}$ while the lowest values are measured during summer, $0.12 \mathrm{mg} \mathrm{m}^{-3}$. For BTX, the highest values are registered in spring (benzene 1.5, toluene 10.8, and $\mathrm{m}$, p-xylene $3.6 \mu \mathrm{g} \mathrm{m}^{-3}$ ) and the levels decrease up to reach the minimum values in August (benzene 0.4, toluene 2.6, and $\mathrm{m}$,p-xylene $1 \mu \mathrm{g} \mathrm{m}^{-3}$ ). Maximum monthly averages were in $\mu \mathrm{g} \mathrm{m}^{-3}$ : 31 (PM10) in August, 2 (benzene) in November, 12 (toluene) in March, 4 (m,p-xylene) in May and $0.3 \mathrm{mg}$ $\mathrm{m}^{-3}$ (CO) in November. The mean values of CO, PM10, benzene, toluene and $\mathrm{m}, \mathrm{p}$-xylene during the whole measurements period were: $0.2 \mathrm{mg} \mathrm{m}^{-3}, 20.7 \mu \mathrm{g} \mathrm{m}^{-3}, 1.2 \mu \mathrm{g} \mathrm{m}^{-3}, 6.4 \mu \mathrm{g}$ $\mathrm{m}^{-3}$ and $2.4 \mu \mathrm{g} \mathrm{m}^{-3}$ respectively.

Regarding BTX, the average level of benzene found in this study during the whole period was $1.2 \mu \mathrm{g} \mathrm{m}^{-3}$ as mentioned above, with the highest concentration reaching $2 \mu \mathrm{g} \mathrm{m}^{-3}$. This is comparable with the results published by Fernandez-Villarrenaga et al., 2004 concerning benzene levels in Coruña (Spain); the annual mean was $3.4 \mu \mathrm{g} \mathrm{m}^{-3}$ while Cocheo et al., 2000 reported urban concentrations in a few European cities as a mean annual average of $4.4 \mu \mathrm{g}$ $\mathrm{m}^{-3}$ for Antwerp, $3.1 \mu \mathrm{g} \mathrm{m}^{-3}$ for Copenhagen and much higher for the South European cities. 
In the present study, the obtained mean concentration was lower, due to the fact that Ciudad Real is not a big city. Toluene and m,p-xylene had concentrations either in the same range or lower than the ones reported for other urban areas, especially North European cities (Derwent et al., 2000).
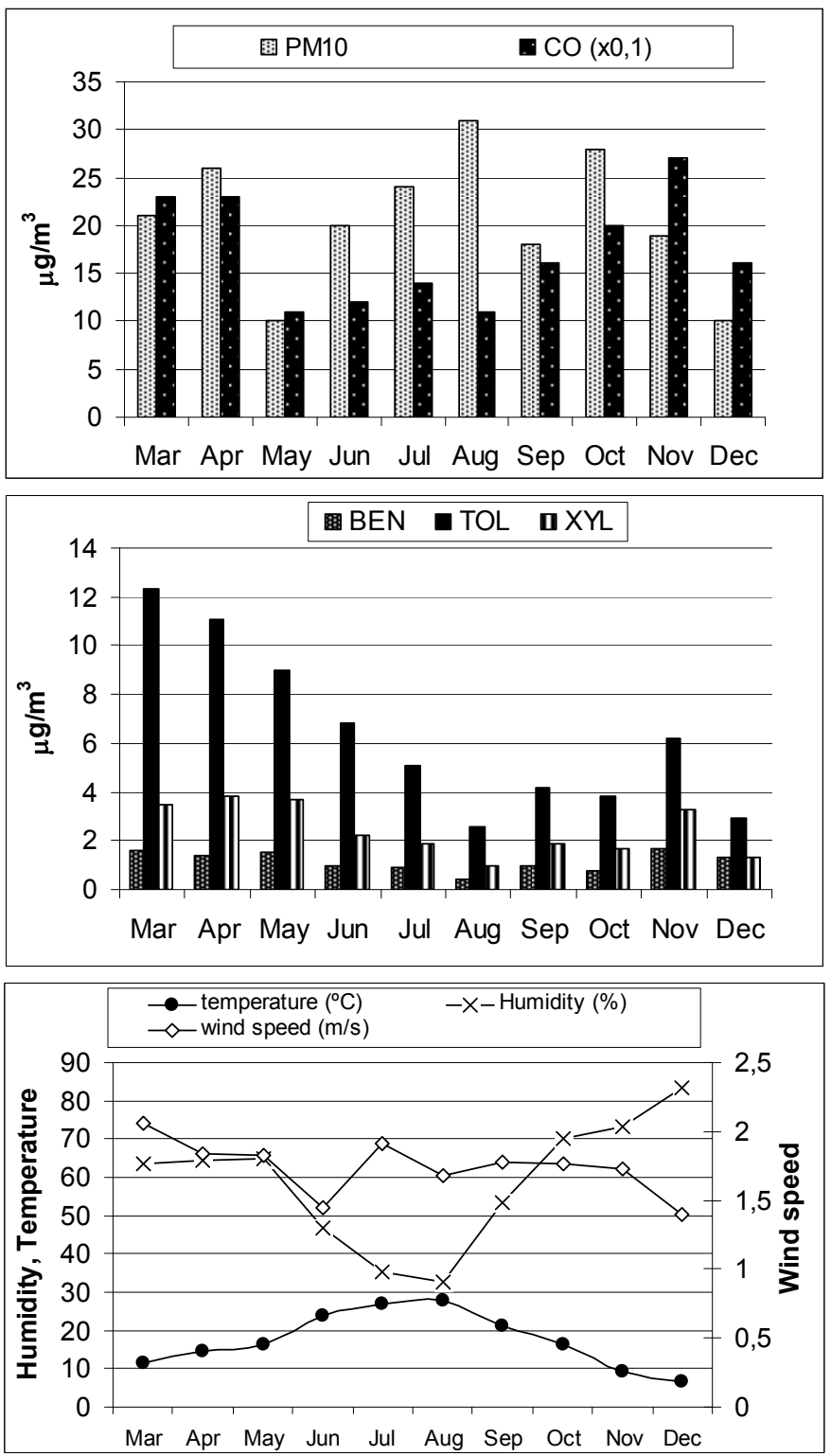

Fig. 11. Monthly means of CO, PM10 and BTX measured from daily data. The meteorological parameters are also presented. 
The variation in the particulate matter concentration throughout the study, as mentioned above, has not a clear trend and there is not a clear relation to meteorological parameters such as wind speed that is below $2 \mathrm{~m} \mathrm{~s}^{-1}$ (in the whole period), temperature or humidity (Figure 11). This correlation was observed in the study carried out by Kulshrestha et al., 2009. PM10 concentrations in Ciudad Real must be conditioned for natural processes of the pollutants such as dust intrusion from Sahara desert, fires, etc., together with road activities and re-suspension of road dust. The mean value obtained in this study was 20.7 $\mu \mathrm{g} \mathrm{m}^{-3}$. This value is lower than those reported in other urban areas in Spain (Querol et al., 2008).

Regarding limit and threshold environmental levels values, the European Directive 2008/50/EC defines the threshold to protect the human health as a daily value of $50 \mu \mathrm{g} \mathrm{m}^{-3}$. This value was exceeded 4 times during the period of study, in all cases during the warm season. The highest daily concentration was $56 \mu \mathrm{g} \mathrm{m}^{-3}$. On the other hand, since EU has not guide value for toluene and xylenes, we compare our measurements with WHO, 2000b, recommended air guideline for toluene (9-10 ppb for $24 \mathrm{~h}$ ). The values measured in Ciudad Real are below these limits.

\section{Conclusion}

We analyse in this study, the air quality of an urban atmosphere, Ciudad Real (in centralsouthern Spain) through different monitoring techniques. We perform a comparison study on four trace gases $\left(\mathrm{O}_{3}, \mathrm{NO}, \mathrm{NO}_{2}\right.$ and $\left.\mathrm{SO}_{2}\right)$ using three different measurement techniques: a commercial DOAS system (Opsis, Sweden), conventional analyzers (API-Teledyne, USA) placed at a mobile station and passive samplers (Radiello, Italy). The results showed a fairly good agreement between the monitoring methods considering the differences in the techniques, the different time period and meteorological situations found during the different years and also the altitude and location of the instruments. In this study, measurement of BTX, CO and PM10 carried out with the mobile station for first time in Ciudad Real have also been included.

Based on the results of the studies made during the three campaigns (July 2000-March 2001, January-December 2007 and March-December 2008) using different techniques it can be concluded that Ciudad Real has high air quality with no significant changes during the three years monitored and where the pollution mainly comes from road traffic and it is influenced by photochemistry. There are not signs that indicate that the pollution from the petrochemical complex located $30 \mathrm{~km}$ southwest can significantly affect the air quality of Ciudad Real.

\section{References}

Atkinson, R. (2000). Atmospheric chemistry of VOCs and NOx. Atmospheric Environment 34, (12-14), 2063-2101.

Cocheo, V.; Boaretto, C.; Cocheo, L. \& Sacco, P.; (1999). Radial path in diffusion: The idea to improve the passive sampler performances. In V. Cocheo, E. De Saeger, D. Kotzias 
(Eds.), International Conference Air Quality in Europe. Challenges for the 2000's. Venice, Italy.

Cocheo, V.; Sacco, P.; Boaretto, C.; De Saeger, E.; Perez Ballesta, P.; Skov, H.; Goelen, E.; Gonzales, N. and Baeza Caracena, A. (2000). Urban benzene and population exposure. Nature 404, 141-142.

Derwent, R.G.; Davies, T.J.; Delaney, M.; Dollard, G.J.; Field, R.A.; Dumitrean, P.; Nason, P.D.; Jones, B.M.R. \& Pepler, S.A. (2000). Analysis and interpretation of the continuous hourly monitoring data for 26 C2-C8 hydrocarbons at 12 United Kingdom sites during 1996. Atmospheric Environment 34, 297-312.

Fenger, J. (1999). Urban air quality. Atmospheric Environment. 33, 4877-4900.

Fernandez-Villarrenaga, V.; Lopez-Mahia, P.; Muniategui-Lorenzo, S.; Prada- Rodriguez, D.; Fernandez-Fernandez, E. \& Tomas, X. (2004). C1 to C9 volatile organic compound measurements in urban air. Science of the Total Environment 334-335, 167-176.

Finlayson-Pitts, B. J. \& Pitts, Jr., J. N. (2000) Chemistry of the Upper and Lower Atmosphere, Academic Press, New York.

Fuentes, J.D.; Lerdau, M.; Atkinson, R.; Baldocchi, D.; Bottenheim, J.W.; Ciccioli, P.; Lamb, B.; Geron, C.; Gu, L.; Guenther, A.; Sharkey T.D. \& Stockwell, W. (2000). Biogenic hydrocarbons in the atmospheric boundary layer: a review. Bulletin of the American Meteorological Society , 81, 1537-1575.

Gobiet, A.; Baumgartner, D.; Krobath, T.; Maderbacher, R. \& Putz, E. (2000). Urban air pollution monitoring with DOAS considering the local meteorological situation, Environmental Monitoring Assessment. 65, 119-127.

Kleinman, L. I. (1991). Seasonal dependence of boundary layer peroxide concentration: the low and high NOx regimes.Journal of Geophysical Research, 96, 20721-20733.

Kourtidis, K. A.; Ziomas, I.; Zerefos, C.; Kosmidis, E.; Symeonidis, P.; Christophilopoulos, E.; Karathanassis, S. \& Mploutsos, A. (2002). Benzene, toluene, ozone, NO2 and SO2 measurements in an urban street canyon in Thessaloniki, Greece, Atmospheric Environment. 36, 5355-5364.

Kulshrestha, A.; Gursumeeran Satsangy, P.; Masih, J. \& Taneja, A. (2009). Metal concentration of PM2.5 and PM10 particles and seasonal variations in urban and rural environment of Agra, India. Science of the Total Environment 407, 6196-6204.

Lee, D. S., Holland, M. K. \& Falla, N. (1996). The potential impact of ozone on materials in the UK. Atmospheric Environment, 30, 1053-1065.

Martin, P.; Cabañas, B.; Villanueva, F.; Gallego, M.P.; Colmenar, I. \& Salgado, S. (2010). Ozone and Nitrogen Dioxide Levels Monitored in an Urban Area (Ciudad Real) in centralsouthern Spain. Water, Air \& Soil Pollution 208, 305-316.

Mazzeo, N. A. \& Venegas, L. E. (2002). Estimation of cumulative frequency distribution for carbon monoxide concentration from wind-speed data in Buenos Aires (Argentina). Water, Air and Soil Pollution: Focus, 2, 419-432.

Mazzeo, N. A. \& Venegas, L. E. (2004). Some aspects of air pollution in Buenos Aires City. International Journal of Environmental Pollution, 22 (4), 365-379. 
Palacios, M.; Kirchner, F.; Martilli, A.; Clappier, A.; Martin, F. \& Rodriguez, M. E. (2002). Summer ozone episodes in the Greater Madrid area. Analyzing the ozone response to abatement strategies by modelling. Atmospheric Environment. 36, 5323-5333.

Plane J. M. C. \& Saiz-Lopez, A. (2005). UV-visible Differential Optical Absorption Spectroscopy (DOAS), in D.E. Heard (ed.), Analytical Techniques for Atmospheric Measurement. Blackwell Publishing, Oxford.

Platt, U. (1994). Differential optical absorption spectroscopy (DOAS), in M.W. Sigrist (ed.), Air Monitoring by Spectroscopy Techniques. John Wiley, London.

Pujadas, M.; Plaza, J.; Teres, J.; Artinano, B. \& Millan, M. (2000). Passive remote sensing of nitrogen dioxide as a tool for tracking air pollution in urban areas: The Madrid urban pluma, a case of study, Atmospheric Environment. 34, 3041-3056.

Querol, X.; Alastuey, A.; Moreno, T.; Viana, M.M.; Castillo, S.; Pey, J.; Rodríguez, S.; Artiñano, B.; Salvador, P.; Sánchez, M.; Garcia Dos Santos, S.; Herce Garraleta M.D.; Fernandez-Patier, R.; Moreno-Grau, S.; Negral, L.; Minguillón M.C.; Monfort, E.; Sanz, M.J.; Palomo-Marín, R.; Pinilla-Gil, E.; Cuevas, E.; de la Rosa, J. \& Sánchez de la Campa, A. (2008) Spatial and temporal variations in airborne particulate matter (PM10 and PM2.5) across Spain 1999-2005. Atmospheric Environment 42, 3964-3979.

R\&P-Co. (2001). Radiello® Model 3310 passive sampling system. Passive gas sampling system for industrial indoor/Radiello sampler, version 1/2003.

http:/ / www.radiello.com.

Saiz-Lopez, A.; Notario, A.; Martínez, E.; \& Albadalejo, J. (2006). Seasonal evolution of levels of gaseous pollutants in an urban area (Ciudad Real) in central-southern Spain: A DOAS Study. Water, Air \& Soil Pollution 171, 153-167.

Sillman, S. \& Samson, P. J. (1995). Impact of temperature on oxidant photochemistry in urban, polluted rural and remote environment. Journal of Geophysical Research, 100, 1149711508.

Tang, H. \& Lau, T. (1999). A new all-season passive sampling system for monitoring NO2 in air. Field Analytical Chemistry and Technology, 3(6), 338-345.

Toll, I. \& Baldasano, J. M. (2000). Modeling of photochemical air pollution in the Barcelona area with highly disaggregated anthropogenic and biogenic emissions, Atmospheric Environment. 34, 3069-3084.

Vandaele, A. C.; Tsouli, A.; Carleer, M. \& Colin, R. (2002). UV Fourier transform measurements of tropospheric $\mathrm{O} 3, \mathrm{NO}_{2}, \mathrm{SO} 2$, benzene and toluene, Environmental. Pollution. 116, 193-201.

Varshney, C. K. \& Singh, A. P. (2003). Passive samplers for NOx monitoring: a critical review. The Environmentalist, 23(2), 127-136.

Villanueva, F.; Notario A.; Albaladejo, J; Millán M.C. \& Mabilia R; (2010). Ambient air quality in an urban area (Ciudad Real) in central-southern Spain. Fresenius Environmental Bulletin., 19, 2064-2070.

WHO (2000a). Chapter 7.2 Ozone and other photochemical oxidants. Air Quality GuidelinesSecond Edition. Copenhagen: WHO Regional Office for Europe.

WHO (2000b). Air quality guidelines for Europe, European series 91. Copenhagen, Denmark: World Health authority Regional Publications, 1-198. 
Zhang, R.W.; Lei, X. \& TieHess, P. (2004) Industrial emissions cause extreme diurnal urban ozone variability. Proceedings of the National Academy of Sciences, USA, 101, 6346-6350. 


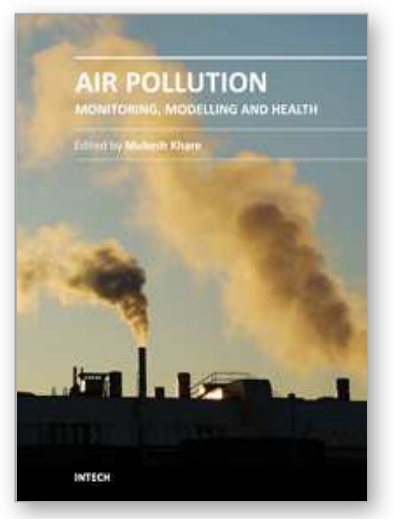

\author{
Air Pollution - Monitoring, Modelling and Health \\ Edited by Dr. Mukesh Khare
}

ISBN 978-953-51-0424-7

Hard cover, 386 pages

Publisher InTech

Published online 23, March, 2012

Published in print edition March, 2012

Air pollution has always been a trans-boundary environmental problem and a matter of global concern for past many years. High concentrations of air pollutants due to numerous anthropogenic activities influence the air quality. There are many books on this subject, but the one in front of you will probably help in filling the gaps existing in the area of air quality monitoring, modelling, exposure, health and control, and can be of great help to graduate students professionals and researchers. The book is divided in two volumes dealing with various monitoring techniques of air pollutants, their predictions and control. It also contains case studies describing the exposure and health implications of air pollutants on living biota in different countries across the globe.

\title{
How to reference
}

In order to correctly reference this scholarly work, feel free to copy and paste the following:

Florentina Villanueva, José Albaladejo, Beatriz Cabañas, Pilar Martín and Alberto Notario (2012). Monitoring Studies of Urban Air Quality in Central-Southern Spain Using Different Techniques, Air Pollution - Monitoring, Modelling and Health, Dr. Mukesh Khare (Ed.), ISBN: 978-953-51-0424-7, InTech, Available from: http://www.intechopen.com/books/air-pollution-monitoring-modelling-and-health/air-quality-analysis-of-anurban-atmosphere-through-different-monitoring-techniques-a-review

\section{INTECH}

open science | open minds

\section{InTech Europe}

University Campus STeP Ri

Slavka Krautzeka 83/A

51000 Rijeka, Croatia

Phone: +385 (51) 770447

Fax: +385 (51) 686166

www.intechopen.com

\section{InTech China}

Unit 405, Office Block, Hotel Equatorial Shanghai

No.65, Yan An Road (West), Shanghai, 200040, China

中国上海市延安西路65号上海国际贵都大饭店办公楼 405 单元

Phone: +86-21-62489820

Fax: $+86-21-62489821$ 
(C) 2012 The Author(s). Licensee IntechOpen. This is an open access article distributed under the terms of the Creative Commons Attribution 3.0 License, which permits unrestricted use, distribution, and reproduction in any medium, provided the original work is properly cited. 